Article

\title{
Antioxidant and Understanding the Anticancer Properties in Human Prostate and Breast Cancer Cell Lines of Chemically Characterized Methanol Extract from Berberis hispanica Boiss. \& Reut
}

\author{
Loubna El Fakir ${ }^{1}$, Kaoutar Bouothmany ${ }^{2}\left(\mathbb{D}\right.$, Amal Alotaibi ${ }^{3, *}$, Mohammed Bourhia ${ }^{4, *(\mathbb{D}, \text { Riaz Ullah }}{ }^{5, *(\mathbb{D})}$,
} Saira Zahoor ${ }^{6}$, Mohamed El Mzibri ${ }^{2}$, Said Gmouh ${ }^{7}$, Tajelmolk Alaoui ${ }^{1}$, Abdelhamid Zaid ${ }^{1}$ and Laila Benbacer ${ }^{2}$

1 Laboratory of Management and Development of Natural Resources, Faculty of Sciences, University Moulay Ismail, Meknes B.P. 11201, Morocco; loubnabenddif@gmail.com (L.E.F.); alauitajelmolk@gmail.com (T.A.); zaid@fs.umi.ac.ma (A.Z.)

2 Laboratory of Pharmacology and Toxicology, Life Science Division, National Centre for Energy, Sciences, and Nuclear Techniques, Rabat B.P. 10001, Morocco; kaoutar.bouothmany@gmail.com (K.B.); mzibri@yahoo.fr (M.E.M.); Benbacer@cnsten.org.ma (L.B.)

3 Basic Science Department, College of Medicine, Princess Nourah Bint Abdulrahman University, Riyadh 11564, Saudi Arabia

check for updates

Citation: El Fakir, L.; Bouothmany, K.; Alotaibi, A.; Bourhia, M.; Ullah, R.; Zahoor, S.; El Mzibri, M.; Gmouh, S.; Alaoui, T.; Zaid, A.; et al. Antioxidant and Understanding the Anticancer Properties in Human Prostate and Breast Cancer Cell Lines of Chemically Characterized Methanol Extract from Berberis hispanica Boiss. \& Reut. Appl. Sci. 2021, 11, 3510. https://doi.org/10.3390/ app11083510

Academic Editor:

Wojciech Kolanowski

Received: 11 March 2021

Accepted: 12 April 2021

Published: 14 April 2021

Publisher's Note: MDPI stays neutral with regard to jurisdictional claims in published maps and institutional affiliations.

Copyright: () 2021 by the authors. Licensee MDPI, Basel, Switzerland. This article is an open access article distributed under the terms and conditions of the Creative Commons Attribution (CC BY) license (https:// creativecommons.org/licenses/by/ $4.0 /)$.
4 Laboratory of Chemistry-Biochemistry, Environment, Nutrition, and Health,

Faculty of Medicine and Pharmacy, University Hassan II, Casablanca B.P. 5696, Morocco

5 Department of Pharmacognosy (MAPPRC), College of Pharmacy, King Saud University, Riyadh 11564, Saudi Arabia

6 Department of Pharmaceutics, College of Clinical Pharmacy, Imam Abdulrehman Bin Faisal University, P.O. Box 1982, Dammam 31441, Saudi Arabia; szahoor@iau.edu.sa

7 Laboratory of Engineering and Materials LIMAT, Faculty of Sciences Ben M'Sik, University Hassan II, Casablanca B.P. 7955, Morocco; said.gmouh@gmail.com

* Correspondence: amaalotaibi@pnu.edu.sa (A.A.); bourhiamoammed@gmail.com (M.B.); rullah@ksu.edu.sa (R.U.)

\begin{abstract}
The current research was conducted to investigate the chemical profile, antiproliferative, and antioxidant activities of methanol extracts obtained by two different methods including maceration and Soxhlet from Berberis hispanica Boiss. \& Reut. Antiproliferative activities were evaluated by the MTT (3-(4, 5-dimethylthiazolyl-2)-2, 5-diphenyltetrazolium bromide) assay in four human cancer cell lines including prostate (LnCap and 22 RV1) and breast cancer (MDA-MB-231 and MCF7). The antioxidant power was evaluated by DPPH ((2,2-diphenyl-1-picryl-hydrazyl-hydrate), ABTS (2,2' -azinobis(3-ethylbenzothiazoline-6-sulfonic acid), and FRAPS (Ferric reducing antioxidant power) tests. The chemical composition was conducted by gas chromatography-mass spectrometry (GC-MS) after methylation. Total phenolic and flavonoid contents were assessed using the Folin-Ciocalteu method. The phytochemical analysis showed that the tested extracts possessed inserting potentially active compounds. The MTT test revealed that both extracts (maceration and Soxhlet) reduced cell viability in all cell lines tested. In breast cancer cell lines MDA-MB-231 and MCF-7, the IC $_{50}$ values obtained by maceration were $16.55 \pm 0.58$ and $17.95 \pm 0.58 \mu \mathrm{g} / \mathrm{mL}$, respectively. These values were slightly lower than those obtained with the Soxhlet extract toward MDA-MB-231 (19.93 $\pm 0.74 \mu \mathrm{g} / \mathrm{mL})$ and MCF-7 $(20.22 \pm 0.89 \mu \mathrm{g} / \mathrm{mL})$. Regarding prostate cancer cells $22 \mathrm{RV}$ and LnCap, the $\mathrm{IC}_{50}$ values obtained by maceration extract (22 RV: $11.75 \pm 0.35 \mu \mathrm{g} / \mathrm{mL}$; LnCap: $11.91 \pm 0.54 \mu \mathrm{g} / \mathrm{mL}$ ) were also slightly lower than those obtained with Soxhlet (22 RV: $13.47 \pm 0.52 \mu \mathrm{g} / \mathrm{mL}$; LnCap: $19.64 \pm 1.05 \mu \mathrm{g} / \mathrm{mL}$ ). The antioxidant activity showed that the studied extracts had considerable antioxidant activity (DPPH, FRAP, and ABTS) with particular attention to the extract obtained with maceration. The Berberis hispanica Bois. and Reut. can serve society as it provides potentially bioactive compounds that may find application in the medical sector to control such diseases.
\end{abstract}

Keywords: Berberis hispanica Bois. and Reut.; antiproliferative activity; GS-MS; antioxidant activity; cancer cell lines 


\section{Introduction}

Since ancient times, humans have developed natural products from plants, marine organisms, and microorganisms for various applications. Interest in natural resources goes back to over 1000 years [1]. Medicinal plants have been used for centuries as remedies, and continue to provide alternative agents to fight various devastating diseases $[2,3]$. Numerous drugs are derived from natural sources including medicinal plants, which can be available in the form of food supplements, nutraceuticals, and complementary alternative medicine [1]. Plants synthesize secondary metabolites with various chemical structures including tannins, terpenoids, alkaloids, and flavonoids, which are involved in several therapeutic pharmacological properties like antimicrobial, anti-oxidants, anticancer, and anti-inflammatory activities [2,4]. Medicinal plants are characterized in priority as an exhaustive source of bioactive compounds that are used in drug development $[4,5]$.

The genus Berberis belongs to the family Berberidaceae with about 500 species. Berberis possesses many medicinal properties since it has been used in the treatment of diseases including leishmaniasis, heart disease, cholecystitis, hypertension, colds, cholelithiasis, dysentery, gallstones, digestive ailments, jaundice, malaria, ischemic heart disease, cardiomyopathies, and urinary tract problems [6-10]. The Spanish barberry is used in traditional medicine to cure gastrointestinal stones, inflammation, liver, and biliary disorders [11]. Genus Berberisis is rich in compounds including tamarixetin, rutin, caffeic, and chlorogenic acids with bioactivity potential. However, the available results on its chemical composition are more limited [10,12]. These compounds are responsible for Berberis biological activities such as antidepressant, antinociceptive, and immunomodulation effects [11,13].

Several works have reported that reactive oxygen species (ROS) are involved in cancer, meanwhile, antioxidant agents are used to counteract them. Plants have been found to contain significant ROS scavenging and antiproliferative activities toward cancer cells. Several studies have shown that plants serve as anticancer agents through apoptosis in numerous cancer cell lines [14].

The goal of this work was to study the phytochemical composition, antioxidant, and antiproliferative activities of Berberis hispanica Boiss. \& Reut. (B. hispanica). These goals may open new approaches to valorize this species as a source of promising agents to fight such diseases.

\section{Material and Methods}

\subsection{Preparation of Plant Extract}

The plant was harvested in September from the region of Errachidia, Morocco. The botanical authentication was done by Dr. Fennan and given the voucher specimen of \#LHE.11 before being deposited at the herbarium. The bark of B. hispanica roots was removed, washed, and dried in the shade at room temperature before being ground into a fine powder. Next, a total of $20 \mathrm{~g}$ of plant powder was extracted with $100 \mathrm{~mL}$ of methanol using two methods including Sand maceration. The Soxhlet was set to $46{ }^{\circ} \mathrm{C}$ for $6 \mathrm{~h}$ and the maceration was done at room temperature for $24 \mathrm{~h}$. Afterward, the mixture was meticulously filtered using Whatman filter paper before being concentrated using a rotary evaporator. The extract obtained was then saved at $4{ }^{\circ} \mathrm{C}$ until further use.

\subsection{Cell Cultures}

Four cancer cell lines were selected for testing including prostate (LnCap and 22RV1) and breast (MDA-MB-231 and MCF-7), which were grown in RPMI (Roswell Park Memorial Institute) and DMEM Dulbecco's Modified Eagle's) medium, respectively. RPMI and DMEM media had $10 \%$ heat-inactivated fetal calf serum, antibiotics, and glutamine with $1 \%$ in each. Cell culture was incubated at $37^{\circ} \mathrm{C}$ and $5 \% \mathrm{CO}_{2}$. Next, cells were washed by PBS followed by trypsin (Gibco, $0.25 \%$ ) for being detached. 


\subsection{In Vitro Antiproliferative Activity Assay}

The viability of cells was estimated based on cell metabolic activity using the MTT assay. Briefly, MDA-MB-231. MCF-7, LnCap, and 22 RV1 cells were adjusted at a density of around 8000 cells per well in plates. After $24 \mathrm{~h}$, the culture medium was replaced with plant concentrations ranging from 4.68 to $150 \mu \mathrm{g} / \mathrm{mL}$. Afterward, the plates were reincubated for $72 \mathrm{~h}$. Next, $100 \mu \mathrm{L}$ of culture medium was replaced with $10 \mu \mathrm{L}$ of MTT reagent before the plates being incubated again for a further $4 \mathrm{~h}$. Cell viability was assessed by measuring the absorbance at $450 \mathrm{~nm}$. Mitomycin was used as a drug reference (positive control) and untreated cells were used as a negative control. The results were expressed as percentages of cell inhibition.

\subsection{Determination of Phenolic Contents}

Total phenolic contents (TPCs) were conducted using methods based on the FolinCiocalteu reagent by Spanos [15] with limited modifications. Briefly, $2.5 \mathrm{~mL}$ of $10 \%(v / v)$. Folin-Ciocalteu chemical was added to $0.5 \mathrm{~mL}$ of the sample solution. Next, the reaction was conducted at $45^{\circ} \mathrm{C}$ for $30 \mathrm{~min}$ before $4 \mathrm{~mL}$ of $7.5 \%(w / v) \mathrm{Na}_{2} \mathrm{CO}_{3}$ being added. The absorbance of the sample was read at $765 \mathrm{~nm}$. TPCs were expressed as $\mathrm{mg}$ GGE/g extract.

\subsection{Determination of Total Flavonoid Content}

The total flavonoid content (TFCs) of B. hispanica extracts was assessed according to the method by Dewanto et al. (2002) [16] with limited modifications. Briefly, $1 \mathrm{~mL}$ of plant extract was mixed with $0.3 \mathrm{~mL}$ of $\mathrm{NaNO}_{3}(5 \%)$ and $0.3 \mathrm{~mL}$ of $1 \%(w / v) \mathrm{AlCl}_{3}$. Next, $2 \mathrm{~mL}$ of $1 \mathrm{M} \mathrm{NaOH}$ was also added to the whole solution before being stirred and allowed to stand. The absorbance of the sample was read at $510 \mathrm{~nm}$. TFCs were expressed as $\mathrm{mg}$ RE/g extract.

\subsection{Evaluation of Antioxidant Activity \\ 2.6.1. DPPH Radical Scavenging Assay}

Radical scavenging activity of plant extracts was evaluated by using the DPPH assay as described by Sayah et al. (2017) [17]. Briefly, $2.5 \mathrm{~mL}$ of different plant concentrations were mixed with a solution of DPPH $(0.2 \mathrm{mM}$ of DPPH). The mixture was vigorously vortexed before being kept in the dark at room temperature for $30 \mathrm{~min}$. Afterward, the absorbance of the sample was read at $517 \mathrm{~nm}$. The antioxidant activity was expressed as a percentage of DPPH inhibition by using the following formula:

$$
\mathrm{DPPH}(\%)=\left[\left(\mathrm{Abs}_{\mathrm{DPPH}}-\mathrm{Abs}_{\text {Sample }}\right) / \mathrm{Abs}_{\mathrm{DPPH}}\right] * 100
$$

where $\mathrm{Abs}_{\mathrm{DPPH}}$ is the absorbance of DPPH used for testing and $\mathrm{Abs}_{\text {sample }}$ is the absorbance of DPPH in the presence of the plant extract tested. The scavenging results were expressed as $\mathrm{IC}_{50}$ (required concentration to inhibit $50 \%$ of free radicals).

\subsubsection{Ferric Reducing Antioxidant Power (FRAP) Assay}

The ferric-reducing capacity of B. hispanica was effectuated using the method of potassium ferricyanide-ferric chloride with limited changes [18]. Briefly, $1 \mathrm{~mL}$ of plant extract was added to a mixture including $2.5 \mathrm{~mL}$ of phosphate buffer $(0.2 \mathrm{M}, \mathrm{pH} 6.6)$ and $2.5 \mathrm{~mL}$ of potassium ferricyanide $(1 \%)$ and then incubated at $50{ }^{\circ} \mathrm{C}$ for $20 \mathrm{~min}$. Next, 2.5 $\mathrm{mL}$ of $10 \%$ trichloroacetic acid was added to the final solution before being centrifuged at $3000 \mathrm{rpm}$ for $1 \mathrm{~min}$. Finally, $2.5 \mathrm{~mL}$ of the supernatant was added to $2.5 \mathrm{~mL}$ of distilled water with $0.5 \mathrm{~mL} \mathrm{FeCl} 3(0.1 \%, w / v)$. The absorbance of the sample was read at $700 \mathrm{~nm}$ and the findings were expressed as $\mathrm{mg} \mathrm{AAE} / \mathrm{g}$ extract.

\subsubsection{Trolox Equivalent Antioxidant Capacity (TEAC) Assay}

TEAC was studied according to the previously reported protocol [18]. Briefly, ABTS radical solution was obtained by mixing $10 \mathrm{~mL}$ of $2 \mathrm{mM}$ ABTS and $100 \mu \mathrm{L}$ of $70 \mathrm{mM}$ 
potassium persulfate at ambient temperature for $16 \mathrm{~h}$. Next, the solution of ABTS + was diluted in methanol to have an absorbance value of about 0.70 at $734 \mathrm{~nm}$. The absorbance was read at $734 \mathrm{~nm}$. Scavenge capability toward ABTS radical was assessed using the following equation:

$$
\text { ABTS scavenging effect }(\%)=\left(\left(\mathrm{A}_{0}-\mathrm{A}_{1}\right) / \mathrm{A}_{0}\right) \times 100
$$

where $\mathrm{A}_{0}$ is the absorbance of the control solution and $\mathrm{A}_{1}$ is the absorbance of the sample solution. Scavenging activity was expressed as $\mathrm{IC}_{50}$.

\subsection{Gas Chromatography-Mass Spectrometry Analysis}

The gas chromatography-mass spectrometry analysis (GC-MS) technique was used in this study to identify phytocomponents present in the studied extract obtained by maceration. GC-MS characterization of the plant extract was conducted after methylation using a PerkinElmer Clarus 580 gas chromatograph equipped with a capillary column ( $5 \%$ phenyl, 95\% methyplisyloxane; $30.0 \mathrm{MX} 250 \mu \mathrm{m}$ ). Helium was used as a carrier gas at $1 \mathrm{~mL} / \mathrm{min}$. The split was $1 / 75$ and the injection volume of the sample was $1 \mu \mathrm{L}$. The temperature of both injection and detection was set to $250^{\circ} \mathrm{C}$ and $280^{\circ} \mathrm{C}$, respectively. The temperature of the furnace was programmed as follows: from $50{ }^{\circ} \mathrm{C}$ to $200{ }^{\circ} \mathrm{C}$ at a rate of $11^{\circ} \mathrm{C} / \mathrm{min}$, then from $200{ }^{\circ} \mathrm{C}$ to $240{ }^{\circ} \mathrm{C}$ at a rate of $6{ }^{\circ} \mathrm{C} / \mathrm{min}$. The identification of phytocomponents was done by comparing the retention times with those of the references obtained from the database of the technique [5].

\subsection{Statistical Analysis}

Data were expressed as means \pm standard deviation of triplicate assays using analysis of variance (ANOVA). Statistical analysis was conducted using GraphPad Prism 6. Values were statically considered significant at a $p$-value $\leq 0.05$.

\section{Results and Discussion}

\subsection{Total Phenolic and Flavonoids Contents}

The phenolic and flavonoids contents were dosed using gallic acid and quercetin calibration curves (Figures 1 and 2). The total phenol and total flavonoid contents are presented in Table 1. Even though the methanol fraction by maceration was found to be noticeably higher in TPC ( $321.56 \pm 3.05 \mathrm{mg}$ GAEs/g extract) and TFC $(118.4 \pm 2.24 \mathrm{REs} / \mathrm{g}$ extract), no statistically significant difference between the two extraction methods was found $(p>0.05)$. The extract obtained by the Soxhlet method was slightly lower in polyphenol $(289.02 \pm 2.32 \mathrm{GAEs} / \mathrm{g})$ and flavonoids $(98.4 \pm 2.56 \mathrm{GAEs} / \mathrm{g})$. The results obtained showed that $B$. hispanica is potentially rich in polyphenols and flavonoids with some differences resulting from the two methods of extraction used (maceration or Soxhlet).

\subsection{Gas Chromatography-Mass Spectrometry (GC-MS) Analysis}

The presence of chemical components in the methanol extract obtained by maceration of B. hispanica was identified by GC-MS after methylation. The results obtained showed that forty-five chemical compounds were identified in the extract (Figure 3; Table 2), among them 2-heptenal, (Z); 2,4-decadiena; 2,4-decadienal; heptadecane; 2,6,10,14-tetramethyl; hexadecane; and 11,14-eicosadienoic acid methyl ester were the chief chemical compounds in the plant extract. The findings of chemical analysis obtained with GC-MS displayed in Table 2 agreed with the results of the total polyphenolic and flavonoid contents presented in Table 1, since both affirm the presence of common chemical classes. 


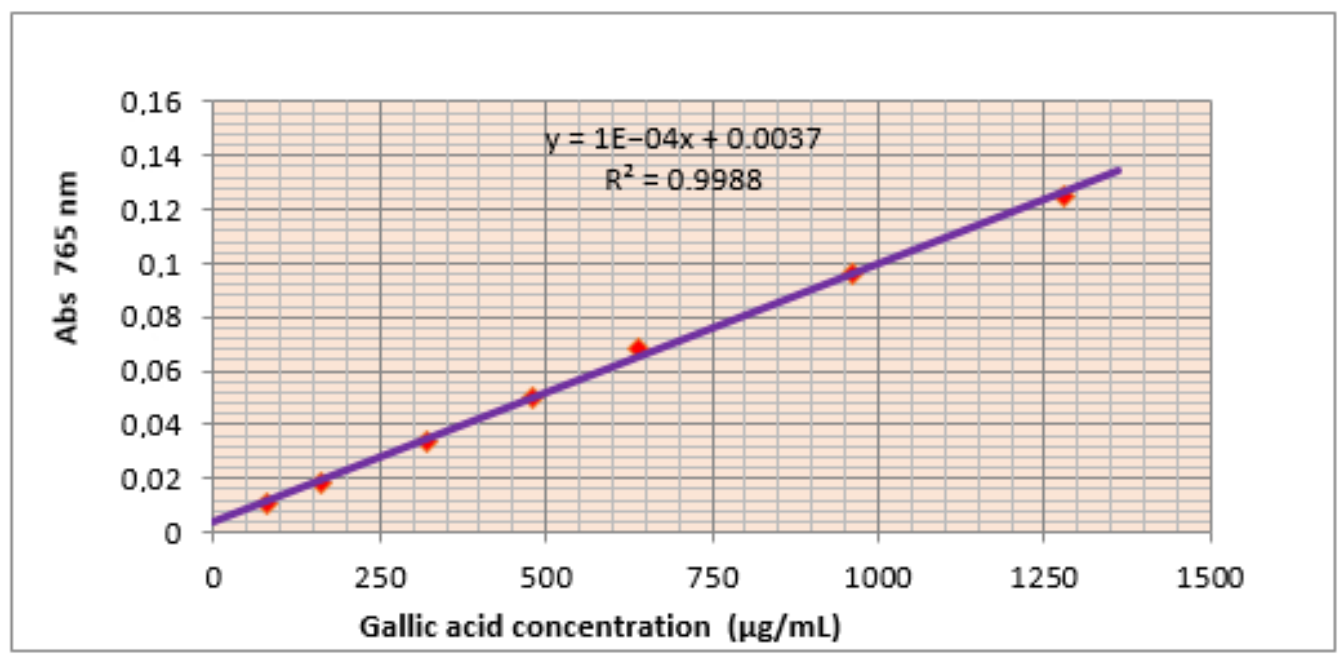

Figure 1. Gallic acid calibration curve used for total phenol quantification.

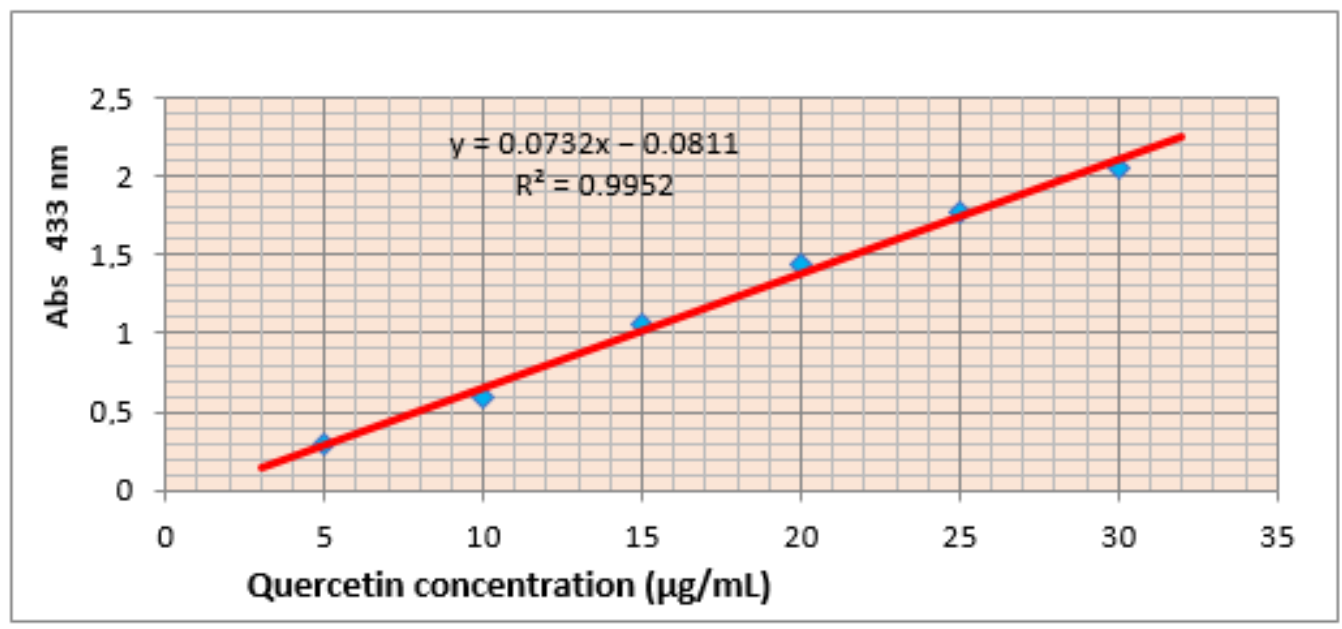

Figure 2. Quercetin calibration curve used for total quantification.

Table 1. Total phenolic and flavonoid contents in B. hispanica extracts.

\begin{tabular}{ccccc}
\hline & \multicolumn{4}{c}{ Methanol Extract } \\
\hline \multirow{3}{*}{$\begin{array}{c}\text { Berberis } \\
\text { Hispanica }\end{array}$} & \multicolumn{2}{c}{ TPC $\mathbf{( m g}$ GAE/g Extract) } & \multicolumn{2}{c}{ TFC (mg RE/g Extract) } \\
\cline { 2 - 5 } & EMM & EMS & EMM & EMS \\
\cline { 2 - 5 } & $321.56 \pm 3.05$ & $289.02 \pm 2.32$ & $118.4 \pm 2.24$ & $98.4 \pm 2.56$ \\
\hline
\end{tabular}

EMM: Extracts obtained with maceration; EMS: Extracts obtained with Soxhlet. Values are expressed as means \pm SD of triplicate assays.

It has been reported in different studies that the pharmacological activities of $B$. hispanica are related to its chemical composition, especially alkaloid and polyphenol classes. The chemical characterization of $B$. hispanica extracts investigated in this work showed the presence of various compounds belonging to these families in the methanolic extracts, which are probably responsible for the antioxidant and antiproliferative activities of the studied plant. The chemical analysis affirmed the presence of many phenolic compounds in the extract like N-(1-Hydroxy-4-oxo-1-phenylper hydroquinolizin-3-yl) carbamic acid, benzyl ester; benzoic acid 3-methyl-4-(1,3,3,3-tetrafluoro-2-methoxycarbonyl-propenylsulfanyl)-phenylester, and Decan-2-yl trimethylsilyl phthalate 1,2 Benzenedicarboxylic acid. Therefore, we can confirm that the chemical content of the studied plant is strongly correlated to the biological outcomes. 


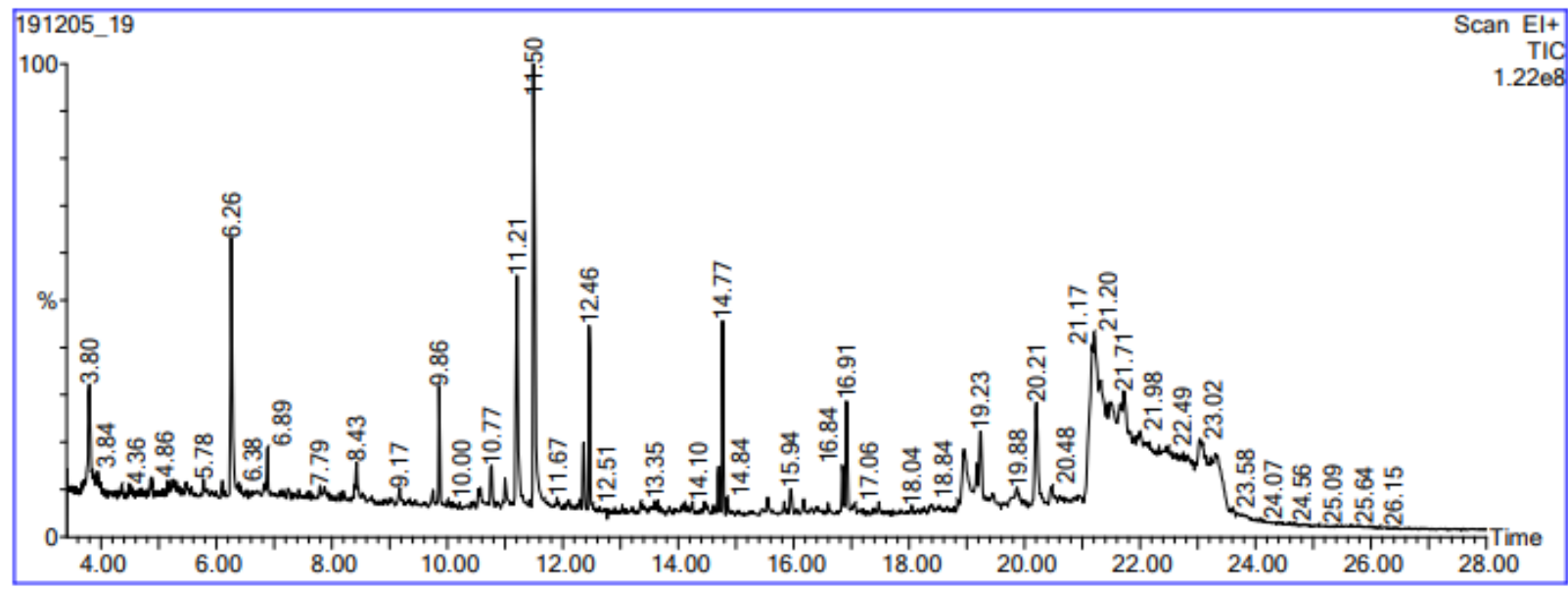

Figure 3. Chromatogram of the characterized extract from B. hispanica.

Table 2. Chemical compounds identified in the methanol extract of B. hispanica bark.

\begin{tabular}{|c|c|c|c|c|c|}
\hline & RT & $\begin{array}{l}\text { Molecular Weight } \\
\text { (g/mol) }\end{array}$ & Formula & Compound Name & Area $(\%)$ \\
\hline 1 & 3.80 & 100.16 & $\mathrm{C}_{6} \mathrm{H}_{12} \mathrm{O}$ & Hexanal & 4.542 \\
\hline 2 & 3.84 & 100.16 & $\mathrm{C}_{6} \mathrm{H}_{12} \mathrm{O}$ & 2-Hexen-1-ol, (E) & 4.542 \\
\hline 3 & 4.36 & 130.23 & $\mathrm{C}_{8} \mathrm{H}_{18} \mathrm{O}$ & 1-Heptanol, 3-methyl & 1.062 \\
\hline 4 & 4.86 & 394.5 & $\mathrm{C}_{23} \mathrm{H}_{26} \mathrm{~N}_{2} \mathrm{O}_{4}$ & $\begin{array}{l}\mathrm{N} \text {-(1-Hydroxy-4-oxo-1-phenylperhydroquinolizin-3-yl) } \\
\text { carbamic acid, benzyl ester }\end{array}$ & 1.075 \\
\hline 5 & 5.78 & 130.23 & $\mathrm{C}_{8} \mathrm{H}_{18} \mathrm{O}$ & 3,4-Dimethyl-2-hexano & 0.683 \\
\hline 6 & 6.26 & 112.17 & $\mathrm{C}_{7} \mathrm{H}_{12} \mathrm{O}$ & 2-Heptenal, (Z) & 2.608 \\
\hline 7 & 6.38 & 414.4 & $\mathrm{C}_{19} \mathrm{H}_{14} \mathrm{~F}_{4} \mathrm{O}_{4} \mathrm{~S}$ & $\begin{array}{c}\text { Benzoic acid 3-methyl-4-(1,3,3,3-tetrafluoro-2- } \\
\text { methoxycarbonyl-propenylsulfanyl)-phenyl } \\
\text { ester }\end{array}$ & 0.250 \\
\hline 8 & 6.89 & 184.36 & $\mathrm{C}_{13} \mathrm{H}_{28}$ & 2,5,6-Trimethyldecane & 0.344 \\
\hline 9 & 7.79 & 142.2 & $\mathrm{C}_{7} \mathrm{H}_{15} \mathrm{ClN}_{2} \mathrm{O}$ & N-Methyl-3-piperidinecarboxamide & 0.250 \\
\hline 10 & 8.43 & 210.4 & $\mathrm{C}_{15} \mathrm{H}_{30}$ & 2,4,6,8-Tetramethyl-1-undecene & 0.552 \\
\hline 11 & 9.17 & 186.33 & $\mathrm{C}_{12} \mathrm{H}_{26} \mathrm{O}$ & 1-Octanol, 2-butyl- & 0.552 \\
\hline 12 & 9.86 & 170.33 & $\mathrm{C}_{12} \mathrm{H}_{26}$ & Dodecane & 0.698 \\
\hline 13 & 10.0 & 166.26 & $\mathrm{C}_{11} \mathrm{H}_{18} \mathrm{O}$ & $\begin{array}{c}\text { 1-Oxaspiro } \\
\text { [2.2]pentane,5-isopropylidene-2,2,4,4-tetramethyl }\end{array}$ & 0.344 \\
\hline 14 & 10.77 & 154.25 & $\mathrm{C}_{10} \mathrm{H}_{18} \mathrm{O}$ & 2-Decenal, (Z) & 0.438 \\
\hline 15 & 11.21 & 152.23 & $\mathrm{C}_{10} \mathrm{H}_{16} \mathrm{O}$ & 2,4-Decadiena & 2.340 \\
\hline 16 & 11.50 & 152.23 & $\mathrm{C}_{10} \mathrm{H}_{16} \mathrm{O}$ & 2,4-Decadienal & 3.786 \\
\hline 17 & 11.67 & 138.21 & $\mathrm{C}_{9} \mathrm{H}_{14} \mathrm{O}$ & 2,4-Nonadienal & 3.786 \\
\hline 18 & 12.46 & 296.6 & $\mathrm{C}_{21} \mathrm{H}_{44}$ & Heptadecane,2,6,10,14-tetramethyl- & 1.290 \\
\hline 19 & 12.51 & 268.5 & $\mathrm{C}_{19} \mathrm{H}_{40}$ & 2,3-Dimethylheptadecane & 1.290 \\
\hline 20 & 13.35 & 198.39 & $\mathrm{C}_{14} \mathrm{H}_{30}$ & Tetradecane & 1.290 \\
\hline 21 & 14.10 & 224.42 & $\mathrm{C}_{16} \mathrm{H}_{32}$ & 7-Hexadecene, (Z) & 0.276 \\
\hline 22 & 14.77 & 226.41 & $\mathrm{C}_{16} \mathrm{H}_{34}$ & Hexadecane & 1.266 \\
\hline 23 & 14.84 & 184.37 & $\mathrm{C}_{13} \mathrm{H}_{28}$ & Tridecane & 1.266 \\
\hline
\end{tabular}


Table 2. Cont.

\begin{tabular}{|c|c|c|c|c|c|}
\hline & RT & $\begin{array}{l}\text { Molecular Weight } \\
\text { (g/mol) }\end{array}$ & Formula & Compound Name & Area (\%) \\
\hline 24 & 15.94 & 201.22 & $\mathrm{C}_{12} \mathrm{H}_{11} \mathrm{NO}_{2}$ & trans-Ethylalpha cyanocinnamate & 0.313 \\
\hline 25 & 16.84 & 186.33 & $\mathrm{C}_{12} \mathrm{H}_{26} \mathrm{O}$ & 2-Dodecanol & 0.435 \\
\hline 26 & 16.91 & 212.42 & $\mathrm{C}_{15} \mathrm{H}_{32}$ & Pentadecane & 1.075 \\
\hline 27 & 17.06 & 184.36 & $\mathrm{C}_{13} \mathrm{H}_{28}$ & 2-Methyldodecane & 1.075 \\
\hline 28 & 18.04 & 256.42 & $\mathrm{C}_{16} \mathrm{H}_{32} \mathrm{O}_{2}$ & n-Hexadecanoicacid & 1.993 \\
\hline 29 & 18.84 & 280.5 & $\mathrm{C}_{20} \mathrm{H}_{40}$ & 9-Eicosene, (E) & 0.643 \\
\hline 30 & 19.23 & 212.41 & $\mathrm{C}_{15} \mathrm{H}_{32}$ & Dodecane, 2,6,10-trimethyl & 1.325 \\
\hline 31 & 19.88 & 378.6 & $\mathrm{C} 21 \mathrm{H} 34 \mathrm{O} 4 \mathrm{Si}$ & $\begin{array}{c}\text { Decan-2-yl trimethylsilyl phthalate 1,2 } \\
\text { Benzenedicarboxylic acid }\end{array}$ & 0.702 \\
\hline 32 & 20.21 & 292.25 & $\mathrm{C}_{16} \mathrm{H}_{11} \mathrm{~F}_{3} \mathrm{O}_{2}$ & 1-fluorenecarboxylic acid, 2,2,2-trifluoroethyl ester & 1.662 \\
\hline 33 & 20.48 & 324.6 & $\mathrm{C}_{23} \mathrm{H}_{48}$ & Heptadecane, 9-hexyl & 0.320 \\
\hline 34 & 21.17 & 322.5 & $\mathrm{C} 21 \mathrm{H} 38 \mathrm{O} 2$ & 11,14-Eicosadienoic acid, methyl ester & 14.287 \\
\hline 35 & 21.20 & 280.4 & $\mathrm{C}_{18} \mathrm{H}_{32} \mathrm{O}_{2}$ & Linoelaidic acid & 14.287 \\
\hline 36 & 21.71 & 254.5 & $\mathrm{C}_{18} \mathrm{H}_{38}$ & 2,6,10-trimethyl-pentadecane & 7.151 \\
\hline 37 & 21.98 & 212.42 & $\mathrm{C}_{15} \mathrm{H}_{32}$ & Pentadecane & 7.151 \\
\hline 38 & 22.49 & 166.26 & $\mathrm{C}_{11} \mathrm{H}_{18} \mathrm{O}$ & 2,6-Nonadienal, 3,7-dimethyl & 15.390 \\
\hline 39 & 23.02 & 240.5 & $\mathrm{C}_{17} \mathrm{H}_{36}$ & Tetradecane, 2,6,10-trimethyl & 3.445 \\
\hline 40 & 23.58 & 272.9 & $\mathrm{C}_{17} \mathrm{H}_{33}$ & 7-Heptadecene & 15.390 \\
\hline 41 & 24.07 & 100.16 & $\mathrm{C}_{6} \mathrm{H}_{12} \mathrm{O}$ & 2-Hexen-1-ol, (E) & 0.514 \\
\hline 42 & 24.56 & 118.17 & $\mathrm{C}_{6} \mathrm{H}_{14} \mathrm{O}_{2}$ & meso-3,4-Hexanediol & 0.529 \\
\hline 43 & 25.09 & 130.23 & $\mathrm{C}_{8} \mathrm{H}_{18} \mathrm{O}$ & 2-Hexanol, 3,4-dimethyl & 0.683 \\
\hline 44 & 25.64 & 112.17 & $\mathrm{C}_{7} \mathrm{H}_{12} \mathrm{O}$ & 2-Heptenal, (E) & 0.324 \\
\hline 45 & 26.15 & 170.33 & $\mathrm{C}_{12} \mathrm{H}_{26}$ & Dodecane & 0.698 \\
\hline
\end{tabular}

It was demonstrated that the rutin and tamarixetin contained in Berberis were responsible for the inhibition of cancer cell lines in a concentration-or time-dependent manner by inducing apoptosis and blocked cell cycle progression at the G2-M phase [10]. Antiproliferative activity in breast (MCF-7), colon (Caco-2), and pancreas (BxPC-3) cancer cell lines induced by Genus berberis was well reported elsewhere (21). Moreover, rutin exhibited a dose-or time-dependent inhibitory effect on U-937 and HT-60 and glioma human cancer cell lines [12,19-22]. Fernández-Poyatos et al. (2020) [12] reported that the most abundant compounds found in B. hispanica are phenolic acids, primarily chlorogenic acid and other caffeoylquinic acids. These compounds have been reported to have antioxidant effects $[10,23]$. Moreover, these compounds have also been shown to possess an in vivo and in vitro anticancer activity in various cancerous cell lines including MCF-7, HCT-116, Hep-G2, and PC-3. Some compounds from caffeoylquinic acids were reported to have an inhibitory effect on the stomach (KatoIII), colon (DLD-1), and promyelocytic leukemia cancer cell lines (HL-60) [24,25].

The results obtained in this work showed that $B$. hispanica possesses interesting antioxidant and antiproliferative activities, which can be explained by its richness in phenolic, alkaloids, and other potentially bioactive compounds. This species appears to be an interesting source of various compounds, which can be applied in medicines to fight such diseases. 


\subsection{Antioxidant Activity}

In the current work, plant extracts were tested for their antioxidant capacity using different tests including DPPH, ABTS radical scavenging capacity, and FRAP (Table 3). The results of the DPPH test showed that the extract tested had scavenging activity in a dose-dependent manner. The extracts showed a potent antioxidant activity, especially that obtained by maceration extract with $\mathrm{IC}_{50}=0.180 \pm 0.020 \mathrm{mg} / \mathrm{mL}$ when compared to the one obtained by Soxhlet extraction ( $\mathrm{IC}_{50}=0.210 \pm 0.017 \mathrm{mg} / \mathrm{mL}$ ), however, no significant difference was observed between the two methods $(p>0.05)$.

Table 3. Antioxidant activity of B. hispanica by DPPH, FRAP, and ABTS.

\begin{tabular}{cccc}
\hline & $\begin{array}{c}\text { DPPH (IC50 in } \\
\mathbf{m g} / \mathbf{m L})\end{array}$ & $\begin{array}{c}\text { ABTS (mg TE/g } \\
\text { Extract) }\end{array}$ & $\begin{array}{c}\text { FRAP (mg AAE/g } \\
\text { Extract) }\end{array}$ \\
\hline EMS & $0.210 \pm 0.017$ & $56.564 \pm 1.63$ & $79.4 \pm 0.45$ \\
\hline EMM & $0.180 \pm 0.020$ & $60.203 \pm 0.76$ & $80.066 \pm 3.28$ \\
\hline BHT & $0.029 \pm 0.006$ & & \\
\hline Ascorbic acid & $0.007 \pm 0.001$ & & \\
\hline Trolox & $1.93 \pm 0.05$ & & \\
\hline
\end{tabular}

EMM: Extracts obtained with maceration; EMS: Extracts obtained with Soxhlet.

Regarding the FRAP bioassay, the highest reducing power was interestingly observed with the maceration extract $(80.066 \pm 3.28 \mathrm{AAE} / \mathrm{g}$ extract $)$ when compared to the one obtained by the Soxhlet method (79.4 $\pm 0.45 \mathrm{mg} \mathrm{AAE} / \mathrm{g}$ extract). In these tests, $B$. hispanica revealed interesting antioxidant activity with insignificant differences between the two methods of extraction.

For the antioxidant activity measured by the ABTS method, we noted that both extracts exhibited potent antioxidant activity in a dose-dependent manner in the DPPH test. The ability of the extracts to scavenge the ABTS cation is presented in Table 2. The B. hispanica extract obtained by maceration showed the highest antioxidant ability $(60.203 \pm 0.76 \mathrm{mg}$ $\mathrm{TE} / \mathrm{g}$ extract) when compared with the Soxhlet extract (56.564 $\pm 1.63 \mathrm{mg}$ TE/g extract).

The obtained results showed that the plant possessed potent antioxidant activity with $\mathrm{IC}_{50}=0.180 \pm 0.020 \mathrm{mg} / \mathrm{mL}$ for the extract obtained by maceration, and $\mathrm{IC}_{50}=$ $0.210 \pm 0.017 \mathrm{mg} / \mathrm{mL}$ for the Soxhlet extract in the DPPH assay. In the present work, we used different methods to evaluate the antioxidant potential of $B$. hispanica methanolic extract; using the ATBS bioassay, maceration, and Soxhlet extracts showed values of $60.203 \pm 0.76 \mathrm{mg}$ TE/g and $56.564 \pm 1.63 \mathrm{TE} / \mathrm{g}$ extract, respectively. The FRAP assay showed that maceration and Soxhlet extracts scored values of $80.066 \pm 3.28 \mathrm{mg}$ AAE/g extract and $79.4 \pm 0.45 \mathrm{mg}$ AAE/g extract, respectively. These results were in close accordance with those reported by Fernández-Poyatos et al. (2020) [12], who revealed that methanolic and aqueous extracts from Spanish species exhibited antioxidant activity with 648 and $212 \mathrm{mmol}$ Trolox equivalent $\mathrm{g}^{-1}$ dried extracts, respectively.

These three methods differ from each other due to characteristics such as substrate type, reaction conditions, and data quantitation methods [18]. A complete picture of the total antioxidant capacity of the methanol extracts from B. hispanica was obtained via analysis of FRAP, DPPH, and ABTS, which showed that studied plant extracts can show different antioxidant power.

\subsection{In Vitro Antiproliferative Activity Assay}

The MTT assay revealed that $B$. hispanica extracts have a potent antiproliferative effect on both breast and prostate cancer cells in a dose-dependent manner after $72 \mathrm{~h}$ of treatment (Figures 4 and 5; Table 4). The cytotoxic effect of extracts on the morphology of cancer cells tested can be observed under the phase-contrast inverted microscope after cell incubation with different concentrations of plant extracts. Treatment of breast (MDA-MB-231, MCF-7) and prostate (22-RV, LnCap) human cancer cell lines for $72 \mathrm{~h}$ with increasing concentrations 
of extracts from B. hispanica induced morphological changes (cancer cell detached as well as the loss of anchor properties) when compared to untreated cells (cancer cells attached to neighbors with preservation of anchor properties) revealing that all lines underwent cell death (Figures 4 and 5).
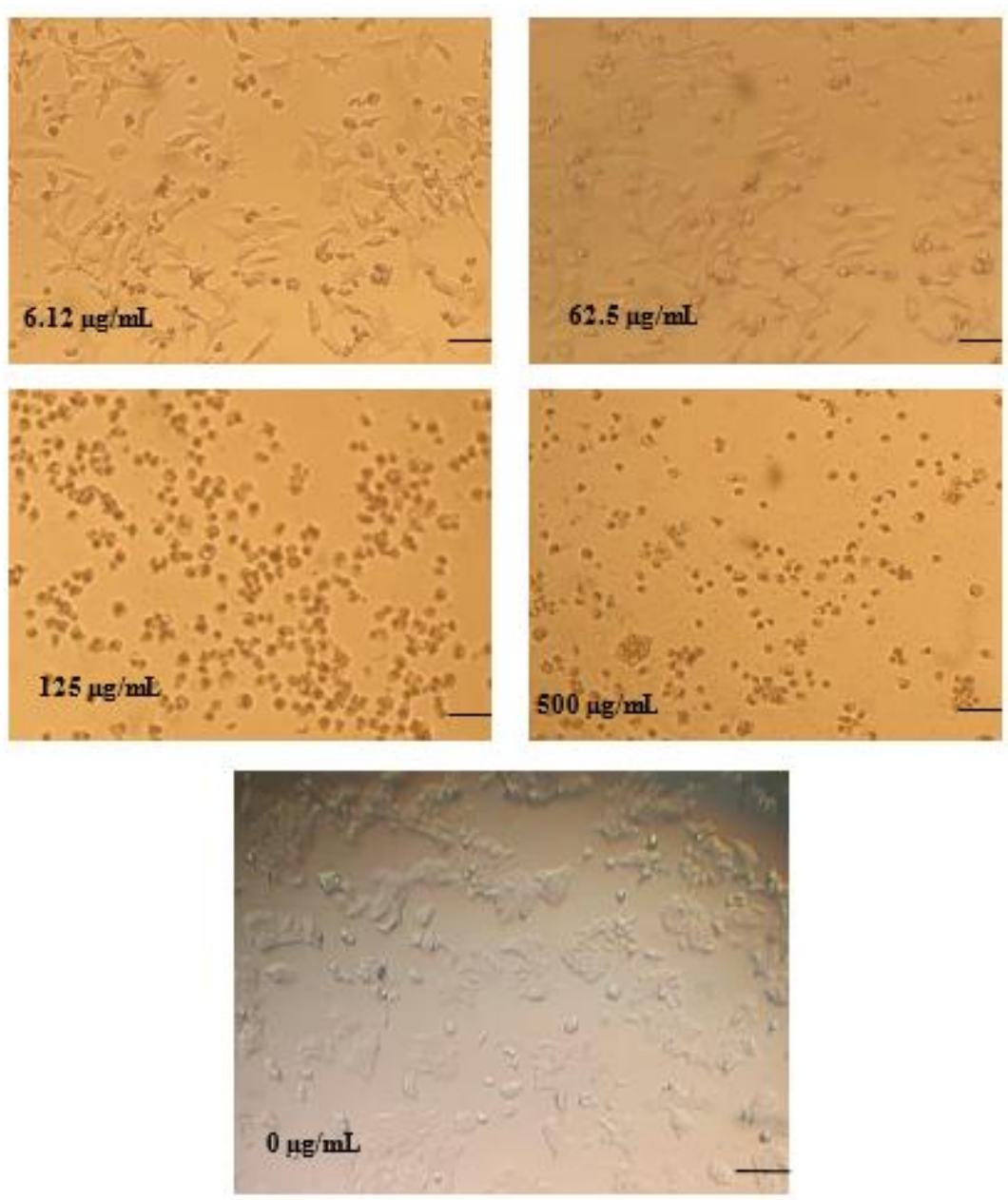

Figure 4. Photograph of cancer cell lines after being treated with $B$. hispanica extracts. $(\times 10$; scale bar $=0.5 \mathrm{~cm})$.

The methanolic extract showed higher antiproliferative activity in both breast and prostate cancer cell lines (Figures 4 and 5; Table 4). Indeed, in breast cancer cell lines MDA-MB-231 and MCF-7, the $\mathrm{IC}_{50}$ values obtained by the maceration extract were 16.55 $\pm 0.58 \mu \mathrm{g} / \mathrm{mL}$ and $17.95 \pm 0.58 \mu \mathrm{g} / \mathrm{mL}$, respectively. The values were slightly lower than the $\mathrm{IC}_{50}$ values obtained with the Soxhlet extract MDA-MB-231 $(19.93 \pm 0.74 \mu \mathrm{g} / \mathrm{mL})$ and MCF-7 (20.22 $\pm 0.89 \mu \mathrm{g} / \mathrm{mL})$. Regarding prostate cancer cells $22 \mathrm{RV}$ and LnCap, the $\mathrm{IC}_{50}$ values obtained by the maceration extract (22 RV: $11.75 \pm 0.35 \mu \mathrm{g} / \mathrm{mL}$; LnCap: $11.91 \pm 0.54 \mu \mathrm{g} / \mathrm{mL}$ ) were also lower than those obtained with Soxhlet (22 RV: $13.47 \pm$ $0.52 \mu \mathrm{g} / \mathrm{mL}$; LnCap: $19.64 \pm 1.05 \mu \mathrm{g} / \mathrm{mL}$ ). Even though the maceration extract was found better in reducing cell viability in cancer cell lines, the two extracts (maceration and Soxhlet) did not differ significantly $(p>0.05)$. 


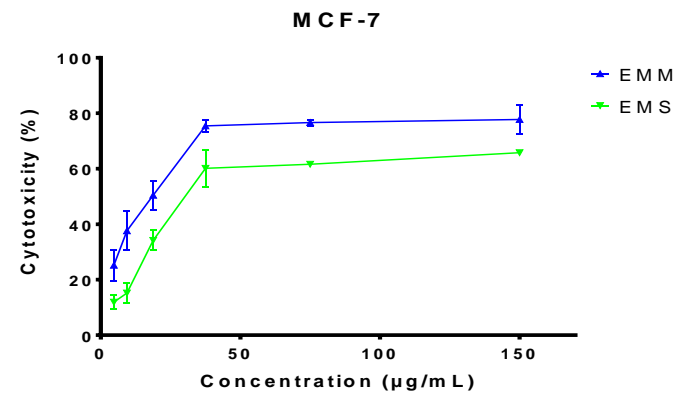

(a)

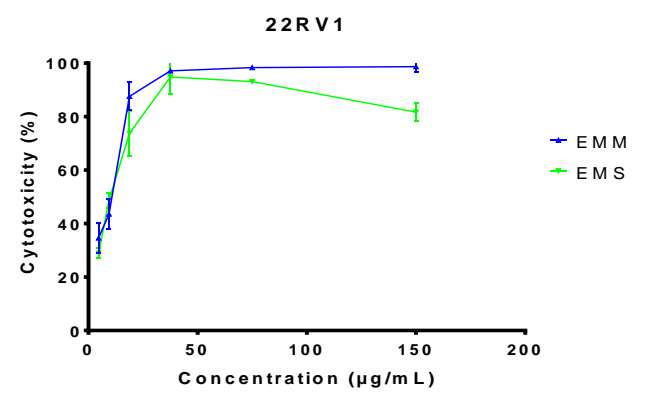

(c)

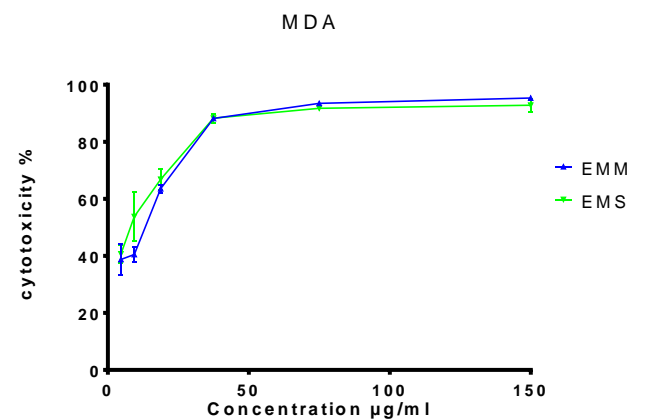

(b)

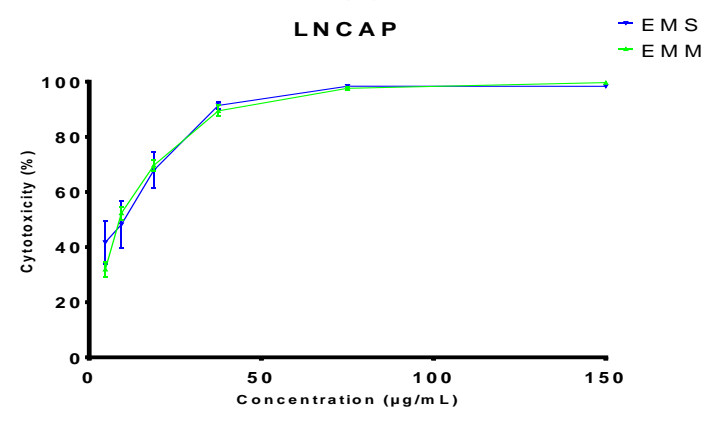

(d)

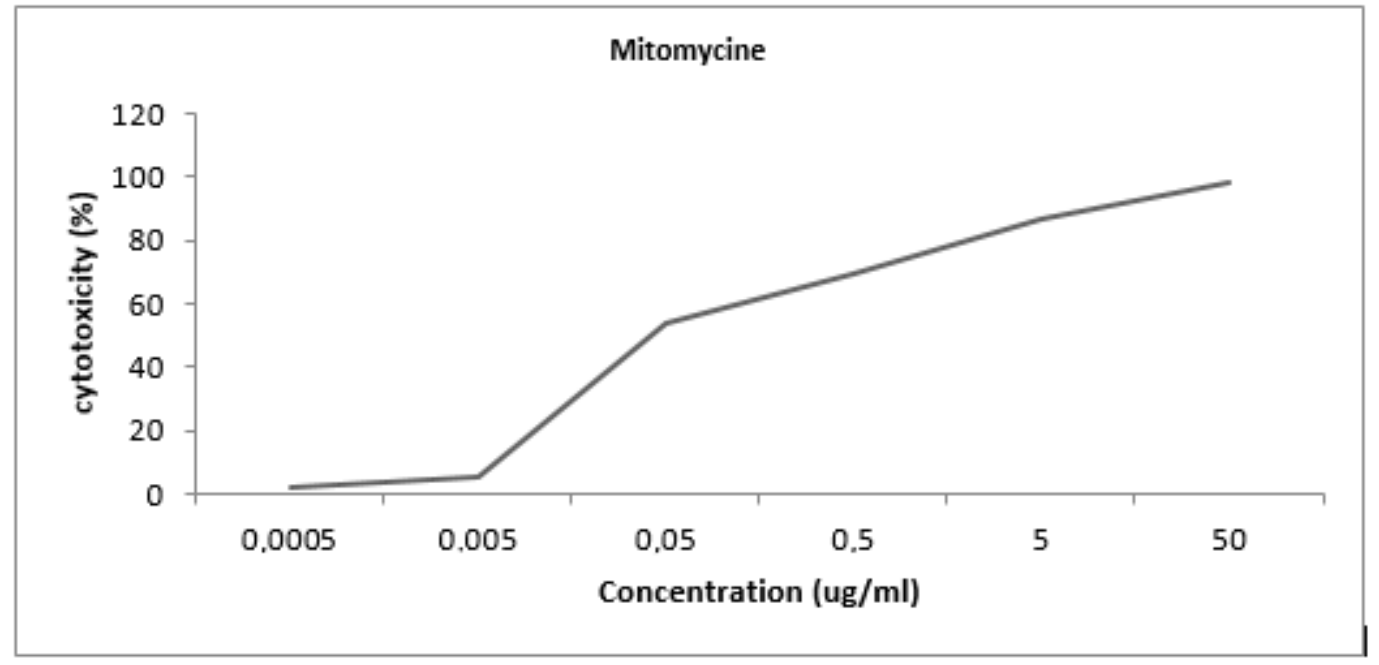

(e)

Figure 5. Antiproliferative effect of methanol extracts obtained by maceration (EMM) and Soxhlet (EMS) from Hispanica bark root in MCF-7 (a), MDA-MB-231(b), 22RV1 (c), LnCap (d) cell lines of $72 \mathrm{~h}$ post-treatment (concentrations ranging from $4.68 \mu \mathrm{g} / \mathrm{mL}$ to $150 \mu \mathrm{g} / \mathrm{mL}$ for both extracts). (e): Effect of mitomycine used as drug reference towrds all cell lines.

Table 4. $\mathrm{IC}_{50}$ values of B. hispanica extracts in MDA MB-231, MCF7, LnCap, and 22rv cell lines.

\begin{tabular}{ccccc}
\hline & MDA-MB-231 & MCF-7 & 22 RV-1 & LnCap \\
\hline EMM $(\mu \mathrm{g} / \mathrm{mL})$ & $16.55 \pm 0.58$ & $17.95 \pm 0.58$ & $11.75 \pm 0.35$ & $11.91 \pm 0.54$ \\
\hline EMS $(\mu \mathrm{g} / \mathrm{mL})$ & $19.93 \pm 0.74$ & $20.22 \pm 0.89$ & $13.47 \pm 0.52$ & $19.64 \pm 1.05$ \\
\hline
\end{tabular}

EMM: Extracts obtained with maceration; EMS: Extracts obtained with Soxhlet.

The results obtained demonstrated that the studied extract possessed antiproliferative potential against the various cell lines resulting in the inhibition of cell proliferation in a dose-dependent manner. In breast cancer cell lines MDA-MB-231 and MCF-7, the $\mathrm{IC}_{50}$ 
values obtained by maceration were $16.55 \pm 0.58$ and $17.95 \pm 0.58 \mu \mathrm{g} / \mathrm{mL}$, respectively, which were slightly lower than those obtained with the Soxhlet extract MDA-MB-231; 19.93 $\pm 0.74 \mu \mathrm{g} / \mathrm{mL}$ and MCF-7; $20.22 \pm 0.89 \mu \mathrm{g} / \mathrm{mL}$. Regarding prostate cancer cells $22 \mathrm{RV} 1$ and LnCap, the $\mathrm{IC}_{50}$ values obtained by the maceration extract $(22 \mathrm{RV} 1: 11.75 \pm 0.35 \mu \mathrm{g} / \mathrm{mL}$; LnCap: $11.91 \pm 0.54 \mu \mathrm{g} / \mathrm{mL}$ ) were also lower than those obtained with Soxhlet (22 RV1: $13.47 \pm 0.52 \mu \mathrm{g} / \mathrm{mL}$; LnCap: $19.64 \pm 1.05 \mu \mathrm{g} / \mathrm{mL}$ ). Therefore, we can confirm that our extract of $B$. hispanica possesses an important anti-proliferative activity against different cancerous cell lines. These results agree with those reported in the literature, which showed that genus Berberis contained tamarixetin, rutin, and caffeic acid, all known for their cytotoxic effects against cancer cell lines including HeLa cells with $\mathrm{IC}_{50}>100 \mu \mathrm{g} / \mathrm{mL}$. Moreover, the alkaloid extract from indigenous species to Algeria induced cell death and morphological changes $[13,19]$.

\section{Conclusions}

B. hispanica is a medicinal plant among the family Berberidaceae that has been found to have pharmacological potential as reported in several previous studies. This work was intended to study the chemical profile, antiproliferative, and antioxidant activities of the organic extracts obtained with two different methods of extractions including maceration and Soxhlet. Based on the findings obtained, the studied plant exhibited potent antioxidant and antiproliferative activity toward human prostate and breast cancer cell lines. Moreover, our results showed that both methods of extraction were closely similar in terms of the activities studied, and therefore, did not differ significantly. B. hispanica can serve society as it provides potentially active compounds that may find applications in medical sectors to control such diseases.

Author Contributions: Data curation, L.E.F., M.B., M.E.M., S.G. and A.A.; Formal analysis, K.B., S.Z., S.G., A.Z. and L.B.; Funding acquisition, R.U. and A.A.; Investigation, L.E.F., M.E.M., A.Z., and L.B.; Methodology, L.E.F., K.B., M.E.M., T.A. and A.Z.; Project administration, T.A.; Resources, R.U.; Software, T.A., A.Z., and L.B.; Supervision, A.Z. and A.A.; Validation, K.B., R.U., S.G. and A.A.; Writing-original draft, M.B. and S.Z. All authors have read and agreed to the published version of the manuscript.

Funding: This research was funded by Deanship of Scientific Research at Princess Nourah bint Abdulrahman University Riyadh Saudi arabia.

Institutional Review Board Statement: Not applicable.

Informed Consent Statement: Not applicable.

Data Availability Statement: The data used to support the findings of this study are available from the corresponding author M.B.

Acknowledgments: The authors extend their appreciation to the Deanship of Scientific Research at Princess Nourah bint Abdulrahman University Riyadh Saudi Arabia for funding this work through the Fast-Track Research Funding Program.

Conflicts of Interest: The authors declare that they have no conflicts of interest.

\section{References}

1. Sharma, S.B.; Gupta, R. Drug Development from Natural Resource: A Systematic Approach. Mini-Rev. Med. Chem. 2015, 15, 52-57. [CrossRef]

2. Bourhia, M.; Amrati, F.E.-Z.; Ullah, R.; Alqahtani, A.S.; Bousta, D.; Ibenmoussa, S.; Khlil, N. Coronavirus Treatments: What Drugs Might Work Against COVID-19? Nat. Prod. Commun. 2020, 15. [CrossRef]

3. Ullah, R.; Alqahtani, A.S.; Noman, O.M.A.; Alqahtani, A.M.; Ibenmoussa, S.; Bourhia, M. A review on ethno-medicinal plants used in traditional medicine in the Kingdom of Saudi Arabia. Saudi Biol. Sci. 2020, 27, 2706-2718. [CrossRef] [PubMed]

4. Bourhia, M.; Bari, A.; Ali, S.S.; Benbacer, L.; Khlil, N. Phytochemistry and toxicological assessment of Bryonia dioica roots used in north-African alternative medicine. Open Chem. 2019, 17, 1403-1411. [CrossRef]

5. Amrati, F.E.-Z.; Bourhia, M.; Saghrouchni, H.; Slighoua, M.; Grafov, A.; Ullah, R.; Ezzeldin, E.; Mostafa, G.A.; Bari, A.; Ibenmoussa, S.; et al. Caralluma europaea (Guss.) N.E.Br.: Anti-Inflammatory, Antifungal, and Antibacterial Activities against Nosocomial Antibiotic-Resistant Microbes of Chemically Characterized Fractions. Molecules 2021, 26, 636. [CrossRef] [PubMed] 
6. Fatehi-Hassanabad, Z.; Jafarzadeh, M.; Tarhini, A.; Fatehi, M. The antihypertensive and vasodilator effects of aqueous extract from Berberis vulgaris fruit on hypertensive rats. Phytother. Res. 2005, 19, 222-225. [CrossRef] [PubMed]

7. Fernandez, A.F.; Assenov, Y.; Martin-Subero, J.I.; Balint, B.; Siebert, R.; Taniguchi, H.; Yamamoto, H.; Hidalgo, M.; Tan, A.-C.; Galm, O.; et al. A DNA methylation fingerprint of 1628 human samples. Genome Res. 2012, 22, 407-419. [CrossRef]

8. Mokhber-Dezfuli, N.; Saeidnia, S.; Gohari, A.R.; Kurepaz-Mahmoodabadi, M. Phytochemistry and pharmacology of berberis species. Pharmacogn. Rev. 2014, 8, 8-15. [CrossRef] [PubMed]

9. Bober, Z.; Stępień, A.; Aebisher, D.; Ożóg, L.; Bartusik-Aebisher, D. Fundamentals of the use of Berberis as a medicinal plant. Eur. J. Clin. Exp. Med. 2018, 16, 41-46. [CrossRef]

10. Lemoui, R.; Benyahia, S.; Noman, L.; Bencherchar, I.; Oke-Altuntas, F.; Rebbas, K.; Benayache, S.; Benayache, F.; Demirtas, I. Isolation of phytoconstituents and evaluation of biological potentials of Berberis hispanica from Algeria. Bangladesh J. Pharm. 2018, 13, 179. [CrossRef]

11. Youbi, A.E.H.E.; Bousta, D.; Ouahidi, I.; Aarab, L. Effets antidépresseurs, antinociceptifs et immunomodulateurs des extraits aqueux et protéique de Berberishispanica Boiss. \& Reut. du Maroc. Phytothérapie 2011, 9, 25-32. [CrossRef]

12. del Pilar Fernández-Poyatos, M.; Ruiz-Medina, A.; Salazar-Mendías, C.; Llorent-Martínez, E.J. Spectrophotometric determination of the antioxidant properties and characterization of the phenolic content by high-performance liquid chromatography-diode array detection-tandem mass spectrometry (HPLC-DAD-MS/MS) of Berberis hispanica Boiss. \& Reut. leaves. Anal. Lett. 2020, 54, 646-657. [CrossRef]

13. El Youbi, A. El H.; Bousta, D.; Jamoussi, B.; Greche, H.; El Mansouri, L.; Benjilali, J.; Soidrou, S.H. Activités antioxydante, apoptotique et antiproliférative de Tetraena gaetula (Emb. \& Maire) Beier \& Thulin et de Berberis hispanica Boiss. \& Reut. originaires du Maroc. Phytothérapie 2012, 10, 151-160. [CrossRef]

14. Sammar, M.; Abu-Farich, B.; Rayan, I.; Falah, M.; Rayan, A. Correlation between cytotoxicity in cancer cells and free radicalscavenging activity: In Vitro evaluation of 57 medicinal and edible plant extracts. Oncol. Lett. 2019, 18, 6563-6571. [CrossRef] [PubMed]

15. Spanos, G.A.; Wrolstad, R.E. Influence of processing and storage on the phenolic composition of Thompson Seedless grape juice. J. Agric. Food Chem. 1990, 38, 1565-1571. [CrossRef]

16. Dewanto, V.; Wu, X.; Liu, R.H. Processed Sweet Corn Has Higher Antioxidant Activity. J. Agric. Food Chem. 2002, 50, $4959-4964$. [CrossRef] [PubMed]

17. Sayah, K.; Marmouzi, I.; Naceiri Mrabti, H.; Cherrah, Y.; Faouzi, M.E.A. Antioxidant Activity and Inhibitory Potential of Cistus salviifolius (L.) and Cistus monspeliensis (L.) Aerial Parts Extracts against Key Enzymes Linked to Hyperglycemia. BioMed Res. Int. 2017, 2017, 2789482. [CrossRef]

18. Tuberoso, C.I.G.; Boban, M.; Bifulco, E.; Budimir, D.; Pirisi, F.M. Antioxidant capacity and vasodilatory properties of Mediterranean food: The case of Cannonau wine, myrtle berries liqueur and strawberry-tree honey. Food Chem. 2013, 140, 686-691. [CrossRef]

19. Boudjlida, A.; Kaci, S.; Karaki, S.; Benayad, T.; Rocchi, P.; Smati, D.; Bouguerra Aouichat, S. Berberis hispanica alkaloids extract induced cell death and apoptosis in human laryngeal cancer cells Hep-2. S. Afr. J. Bot. 2019, 125, 134-141. [CrossRef]

20. Alonso-Castro, A.J.; Domínguez, F.; García-Carrancá, A. Rutin Exerts Antitumor Effects on Nude Mice Bearing SW480 Tumor. Arch. Med. Res. 2013, 44, 346-351. [CrossRef]

21. Ben Sghaier, M.; Pagano, A.; Mousslim, M.; Ammari, Y.; Kovacic, H.; Luis, J. Rutin inhibits proliferation, attenuates superoxide production and decreases adhesion and migration of human cancerous cells. Biomed. Pharmacother. 2016, 84, 1972-1978. [CrossRef]

22. Srinivasan, R.; Natarajan, D.; Shivakumar, M.S. In Vitro evaluation of antioxidant, antiproliferative potentials of bioactive extract-cum-rutin compound Isolated from Memecylon edule leaves and its molecular docking study. J. Biol. Act. Prod. Nat. 2016, 6, 43-58. [CrossRef]

23. Kalinowska, M.; Sienkiewicz-Gromiuk, J.; Świderski, G.; Pietryczuk, A.; Cudowski, A.; Lewandowski, W. Zn(II) Complex of Plant Phenolic Chlorogenic Acid: Antioxidant, Antimicrobial and Structural Studies. Materials 2020, 13, 3745. [CrossRef]

24. Liu, W.; Li, J.; Zhang, X.; Zu, Y.; Yang, Y.; Liu, W.; Xu, Z.; Gao, H.; Sun, X.; Jiang, X.; et al. Current Advances in Naturally Occurring Caffeoylquinic Acids: Structure, Bioactivity, and Synthesis. J. Agric. Food Chem. 2020, 68, 10489-10516. [CrossRef] [PubMed]

25. Santana-Gálvez, J.; Villela Castrejón, J.; Serna-Saldívar, S.O.; Jacobo-Velázquez, D.A. Anticancer potential of dihydrocaffeic acid: A chlorogenic acid metabolite. CyTA J. Food 2020, 18, 245-248. [CrossRef] 